Zlatija Jelenković1, Lidija Barjaktarović ${ }^{2}$

${ }^{1}$ Raiffeisen banka a.d. Beograd, Serbia

2University Singidunum Beograd, Serbia

\title{
The Risk Management Functions in the Conditions of Globalization: Case Study of the Republic of Serbia ${ }^{1}$
}

\author{
UDC: 005.334:005.44 \\ 005.332:338.124.2(497.11) \\ DOI: 10.7595/management.fon.2016.0010
}

\begin{abstract}
Globalization, which represents an important transmission mechanism of the crisis, has led to the necessity for controlling various risks of business, setting a new line of management in companies, regardless of the main business activity they are engaged in. The economic crisis in general, and especially the global financial crises (2007 and the present one) led to bankruptcy, and thus to loss of funds of many businesses and individuals. Therefore, it was necessary, on the one hand, to ensure confidence in the financial system and to maintain its stability. On the other hand, the development of corporate governance and separation of functions of ownership and management insisted on the creation of functions that directly report to the owners of capital, such as risk management and internal audit.

The value of this paper is in emphasizing the new management function and raising awareness of the scientific public and businesses about the need for introduction of risk management functions in order to facilitate effective management of enterprises, although the survey (2012-2015) has shown that the existence of legal obligations, in this regard penal policy, is the only thing that effectively establishes and promotes this area.
\end{abstract}

Keywords: globalization, risks of business, enterprise management, risk, management risk

\section{Introduction}

Globalization is often defined as a phenomenon that primarily addresses the macroeconomic level in the relations between high income countries vs. law incomes countries. However, globalization is a microeconomic phenomenon as well, creating a need for new professions, new ways of organization of the company, the new management functions. The main change into organization of enterprises that occurred is a result of the nature of globalization as a transmission mechanism of the crisis, and the necessity to establish a structure to control and manage the risks. Risk management has become an imperative of modern business, not only because of the needs of the enterprise itself, but also because of the international regulation imposed on the financial sector particularly, the issue that has advanced through institutional risk management (Barjaktarović\& Ječmenica, 2011). Although uncertainty and risk represent an integral part of the economic business, risk as a scientific field has a short history (Barjaktarović, 2015).

The COSO organisation (Committee of Sponsoring Organisations) adopted a document on risk management in enterprises - Integrated Framework (Enterprise Risk Management / ERM / - Integrated Frame) in 2004. Management uses this concept to evaluate and improve daily operations, of which it is an integral part. The ERM concept is defined as a process (initiated by the board of directors, management and other employees) which is an integral part of the strategy of the company, in order to identify potential events that could affect the business itself, as well as to improve risk management in the framework of the existing level of readiness for acceptance of a certain risk. This is a discipline of assessment, control,

${ }^{1}$ The research presented in this paper is part of the project "Advancing Serbia's Competitiveness in the Process of EU Accession", no. 47028, in the period 2011-2016, financed by the Ministry of Education, Science and Technological Development of the Republic of Serbia 
financing and monitoring of all risks of the enterprises, with the aim of increasing value for its owners ( orđević \& Kostić, 2012). All risks are discussed at the same time within a coordinated and strategic framework (Beasley et.al., 2008). Furthermore, the authors (Baxter et al., 2013) suggest a link application of the concept of ERM, business performances (measured indicator ROA) and market value of the company, which means that the market responds positively to companies that have a better use of the ERM concept. Also, research (Barjaktarović et al., 2014) has shown that a successful implementation of the ERM concept contributes to increasing the company's value.

According to the IFC (IFC, 2011) corporate governance has to define the structures and processes for the management and control of companies. The basic element of corporate governance is the general structure of corporate governance, which includes the General Assembly of Shareholders, the Board, executive bodies, the Commission Board, the organs of internal control, external supervision, and the corporate secretary.

Referring to the current regulations on Companies in Serbia, establishing of the company's accounting policies and risk management (Law on Commercial Companies, 2015) is under the jurisdiction of the supervisory board or board of directors (depending on the legal form of establishment). Relevant laws on the specific activity (in compliance with Basel II and Solvency II) define the way of risk management in banking and insurance sectors.

This paper aims to show the way of establishing the functions of risk management, the main actors in risk control and the regulatory framework that exists in the world. The main hypothesis is that an institutionalized approach to risk management is achieved so that the businesses can establish risk management function.

The research is based on data publicly available on the website of regulatory bodies in the country (the Ministry of Finance, the National Bank of Serbia / NBS / BSE) and abroad (the Basel Committee and the Committee of European Insurance and Occupational Pensions Supervision), OECD, IFC and AtKearny, in the period from 2012 to 2015. Data included regulations, reports on the work of specific business entities (as the economic entity, and external auditors) and external supervisory authority on the work of the whole sector analyzed - in the case of the Republic Serbia these are: the Central Bank (Narodna banka Srbije hereinafter: NBS for the financial sector), the Belgrade Stock Exchange (for listed companies) and The Serbian Business Register Agency (Agencija za privredne registre hereinafter: APR, for the real sector) .

The sample of companies analyzed includes 4084 companies operating on the day of 30.09 .2015 in the Republic of Serbia, out which 30 are from the banking sector (the whole banking sector), 25 from the insurance sector (the whole insurance sector), 4029 companies operate in the real sector classified as large (including 7 companies whose shares are subject of trade within the Belgrade Stock Exchange (4 Prime listing, 3 Standard listing) and medium-sized companies in accordance with the Serbian Companies Law², which represent over $80 \%$ of all companies in Republic of Serbia based on achieved turnover in 2014.

This analysis is based on the financial statements obtained from the APR for the period $2012-2015$, prepared by the abovementioned group of companies.

According to the set hypothesis, the work consists of five sections, including the introduction and the conclusion chapters. In the second chapter we discuss the establishment of risk management. Thereafter, the third chapter is devoted to the global regulatory framework for risk management. In the fourth chapter, research on risk management at company level in the Republic of Serbia will be shown. The Final considerations will be presented in the end.

${ }^{2}$ According to the Serbian Companies Law, a large company is a company which: a) has more than 250 employees; b) generates an operating profit of more than $€ 35,153,220.39$; c) owns assets in excess of $€ 17,576,606.04$.

Medium-sized company is a company which: a) has between 50 and 250 employees; b) generates operating profit between $€$ 8,838,522.61 and $35,153,220.39 ;$ c) has assets worth between $€ 4,419,265.16$ and 17,576,606.04. 


\section{Establishment of Risk Management}

Risk management has particularly brought into focus by the current financial crisis, in case of both financial and non financial companies. However, according to the OECD (OECD, 2014), there were no official records that could confirm that many companies apply the concept of risk management. According to the research conducted by McKinsey ${ }^{3}$ in 2011 and 2013, in 2011, 44\% of the companies surveyed said their directors reviewed and approved management strategy, 14\% confirmed that their management board had full understanding of risk management, and 14\% of them devoted their time to this problem while in 2013 these results were somewhat better - about one third of directors dealt with the problem of risk.

Risk management business represents a particular frame that mainly includes the identification of certain events and circumstances that are essential for the achievement of the goals of the company (threats and opportunities), assessing their impact, creating a responsible strategy and process monitoring. Tracking or monitoring of possible risks is the responsibility of the task manager. While defending the company from the impact of different risks and opportunities, executives hold and create value for its shareholders, including owners, employees, customers, regulators and society at large.

Managers choose the right strategy for the management of certain risks, which usually involves several stages:

- Avoidance: the current activity leads to an increased risk;

- Reduction: taking action to reduce the potential risk impact;

- Alternative Activity: decision-making and consideration of other possible steps to minimize the risk;

- Share or provide: transform or divide the size of the risk in smaller portions for funding;

- Accept: without taking action, because of the decision that was made on the basis of rational cost / benefit analysis (cost / benefit decision).

To accomplish the company's strategy, managers must share functions in the process of defining and managing business risks. The question is how to implement risk management principles in companies that so far, in an organized manner, have not had this function.

Different consultants provide different ideas and most of them come down to the following functions:

- choose a sponsor among members of top management,

- appoint a chief risk manager who integrates and proposes policy and chairs the Risk Committee for Risk Assessment,

- appoint the other members of the Committee for Risk Assessment and the holders of certain functions,

- develop a framework to implement Risk Policy and ensure the participation of a third party.

It is a fact that companies consider risk management to be the greatest challenge of management.

\section{Regulatory Framework for Determining Risk Management}

Risks that companies face every day, can be divided into:

- financial and

- non-financial.

Financial risks are appropriate primarily for financial institutions, but also for companies whose finances are not part of their core business (the company in its annual reports according to the IFRS reports on capital management, credit risk, market risk and liquidity risk). In addition to this basic risk, most non-financial organizations are affected by other risks such as: risks of IT equipment, environmental protection, food safety and the like (i.e., according to the COSO, strategic, hazardous and operational).

Most attention is being paid to financial risk and risk management, where the most of the progress is made in both the regulation framework (Basel II and III for the banking sector and Solvency II for insurance companies) and in organization of the structure of risk management. Yet, neither of these structures nor rules can be blindly copied by the nonfinancial companies. 
Table 1: Risk governance requirements/recommendations for listed companies

\begin{tabular}{|c|c|c|c|c|c|}
\hline \multirow[b]{2}{*}{ Country } & \multirow[b]{2}{*}{$\begin{array}{l}\text { Board } \\
\text { responsibiliti } \\
\text { es }\end{array}$} & \multicolumn{2}{|c|}{ Board-level committee } & \multirow[b]{2}{*}{$\begin{array}{l}\text { Internal } \\
\text { control/risk } \\
\text { management } \\
\text { system }\end{array}$} & \multirow[b]{2}{*}{ Chief risk officers } \\
\hline & & Audit & Risk & & \\
\hline Argentina & $\mathrm{C}$ & $L / R$ & $\mathrm{C}$ & $\mathrm{C}$ & $\mathrm{C}$ \\
\hline \multicolumn{6}{|l|}{ Australia } \\
\hline Austria & $\mathrm{L} / \mathrm{C}$ & $L^{*} / C^{*}$ & * & $\mathrm{L}$ & $\star$ \\
\hline \multicolumn{6}{|l|}{ Belgium } \\
\hline \multicolumn{6}{|l|}{ Brazil } \\
\hline \multicolumn{6}{|l|}{ Canada } \\
\hline Chile & * & $\mathrm{R}$ & $\mathrm{R}$ & $\mathrm{R}$ & * \\
\hline Czech Republik & $\star$ & $\star$ & $\star$ & $\star$ & $\star$ \\
\hline \multicolumn{6}{|l|}{ Denmark } \\
\hline \multicolumn{6}{|l|}{ Estonia } \\
\hline Finland & * & $C^{*}$ & * & $\mathrm{C}$ & $\star$ \\
\hline \multicolumn{6}{|l|}{ France } \\
\hline Germany & $\mathrm{L} / \mathrm{C}$ & $\mathrm{L} / \mathrm{C}$ & * & $\mathrm{L} / \mathrm{C}$ & * \\
\hline \multicolumn{6}{|l|}{ Greece } \\
\hline Hong Kong, China & $\mathrm{R} / \mathrm{C}$ & $C^{*}$ & * & C & * \\
\hline \multicolumn{6}{|l|}{ Hungary } \\
\hline \multicolumn{6}{|l|}{ Island } \\
\hline India & L/C & $L^{*} / C^{*}$ & * & L/C & $\star$ \\
\hline \multicolumn{6}{|l|}{ Indonesia } \\
\hline \multicolumn{6}{|l|}{ Ireland } \\
\hline Israel & * & $L^{*}$ & * & $\mathrm{R}$ & $L^{*}$ \\
\hline Italy & C & $\mathrm{L}$ & $\mathrm{C}$ & C & $C^{*}$ \\
\hline Japan & $L$ & * & * & $L$ & $\star$ \\
\hline Korea & $\mathrm{C}$ & * & * & * & * \\
\hline Lithuania & * & $C^{*}$ & * & * & * \\
\hline \multicolumn{6}{|l|}{ Luxembourg } \\
\hline Mexico & $\mathrm{L}$ & $\mathrm{L}$ & * & $\star$ & * \\
\hline Netherlands & $\mathrm{C}$ & $C^{*}$ & * & C & * \\
\hline New Zealand & $\star$ & * & * & $\star$ & $\star$ \\
\hline Norway & C & $L^{*}$ & * & $\mathrm{L} / \mathrm{C}$ & * \\
\hline Poland & * & $L^{*}$ & * & $L$ & * \\
\hline Portugal & * & * & * & * & * \\
\hline \multicolumn{6}{|l|}{ Saudi Arabia } \\
\hline Singapore & C & C & C & C & C \\
\hline \multicolumn{6}{|l|}{ Slovak Republic } \\
\hline Slovenia & * & $C^{*}$ & * & C & * \\
\hline Spain & * & $L^{*} / C^{*}$ & * & $\mathrm{L} / \mathrm{C}$ & * \\
\hline Swiden & $\mathrm{C}$ & * & $\star$ & C & * \\
\hline Switzerland & $\mathrm{L}$ & C & * & C & * \\
\hline Turkey & $\mathrm{R}$ & $\mathrm{L}$ & $L$ & $L$ & * \\
\hline United Kingdom & C & C & * & C & * \\
\hline USA & $\mathrm{R}$ & $L^{*} / R^{*}$ & * & $L / R$ & * \\
\hline
\end{tabular}

Notes: "L/R/C" denote laws, regulations, and codes or principles respectively. "*” denotes the absence of a specific requirement or recommendation (outside the financial sector).

Source: OECD 
The analysis of various structures of risk in different companies (Beasley et al. 2005) (Lajily 2009) has concluded that four fundamental elements can be identified in the process of determining risk management needed to develop each company, whether financial or non-financial, as follows:

1. Risk management has to be determined by the head of risk management;

2. Appoint the members of the risk management board and ensure its independence status in relation to the board members;

3. Provide support to the Director General (Chief Executive Officer- CEO).

4. Provide audit by the best auditing firm (Big Four: Deloitte, KPMG, PricewaterhouseCoopers, Ernst \& Young)

In many jurisdictions, as shown in Table 1, risk management is part of regulations issued by the government or possibly the Chamber of Commerce as part of the national business rules. Thus we have the case rules for Companies listed on the stock exchanges of New York (the New York Stock Exchange listed company rules-NYSE), then combined rules of Great Britain (the UK's combined code) or the French rules or code (the French AFEP-MEDEF code).

The holders of risk functions in an enterprise as defined in most of the laws or rules of business are as follows:

1) Board of Management -. "The main role of the board as an internal mechanism of corporate governance is to define the strategic orientation of the Corporation and to supervise and control the work of management in order to satisfy the interests of owners and key stakeholders" (Nikolic, J. and Eric, J., 2011). Also, management is responsible for establishing an appetite for risk acceptance or tolerance, has the responsibility to define a strategy to take risks and to establish a whole system of assessment and risk control. The system must be compatible with the business strategy of the company.

2) Chief Risk Officer (CRO-general manager for risk management) - In companies where this function exist as a separate body (usually large or companies in the financial sector), it is completely divided from the profit center and reports directly to the board of directors rather than the executive committee. But the boss function cannot be successfully applicable without the established system that is purposeful and effective. 3) The Audit Committee: According to EU Directive (2006/43 / EC) on statutory audit, the Audit Board ${ }^{4}$ shall have the task to monitor the effectiveness of internal control in the company, internal audit where it is the applicable management and risk management system. Also, similar rules exist in the US. Members of the audit committee must have additional training, which is defined by law in many countries. According to EU directive for establishment of audit committees (2006/43 / EC) that states "a person can perform a statutory audit only if they have a university education or a corresponding equivalent, have completed a course in theoretical instruction, have done practical work and passed the examination in professional skills at the university or similar equivalent, which was organized / certified for such training by the state." The Directive further requires that the test of proficiency testing includes the part related to risk management and internal control.

\section{Case Study: Republic of Serbia}

The authors conducted a secondary research, by taking it from the website of the regulators (NBS for banks and insurance companies, Belgrade Stock Exchange for listed companies, APR for unlisted companies) as well as by analyzing the data acquired from sites of the sample's companies. Summarized joint research results are presented in Table 2 . The risk management process and the management of funds is the most developed in the banking sector, mostly influenced by the presence of foreign shareholders within banks equity structure and due to the fact that Serbia strives to become a member of the European Union and to harmonize its legislation within this sector, as well as the desire of the NBS to ensure the stability of the financial system of the Republic of Serbia.

On the basis of the available data (NBS website) it can be concluded that the NBS performs: (a) the introduction of new standards in the performance of banks under the Basel agreements and the EU directives,

${ }^{4}$ According to rules of the New York Stock Exchange of listed financial companies those companies are obliged to have a board whose focus will be risk managment exclusively. 
(b) the direct or indirect control related to risk management, with particular attention to credit, market, operational and liquidity risk.

NBS also publishes financial statements of all participants in the banking sector; however, reporting quality differs. Thus, out of the total number of 28 banks that provide financial statements and auditors' reports, 24 banks also provide the information required for the third pillar of Basel II (strategies and policies for risk management, including the competent authorities and responsibilities in the process of risk management, capital structure, capital adequacy, the internal assessment process of capital adequacy, the bank's exposure to risk and approaches to measurement and assessment), which are of varying quality.

Table 2: Risk Management in the Republic of Serbia on 30 $0^{\text {th }}$ Sept., 2015

\begin{tabular}{|c|c|c|c|c|c|c|c|}
\hline $\begin{array}{l}\text { Common } \\
\text { information } \\
\text { which is } \\
\text { prevailing }\end{array}$ & Banks & NBS & $\begin{array}{l}\text { Insurance } \\
\text { Companies }\end{array}$ & NBS & $\begin{array}{l}\text { Large and } \\
\text { medium-size } \\
\text { companies } \\
\text { which are } \\
\text { subject of } \\
\text { analyses }\end{array}$ & $\begin{array}{l}\text { Listed } \\
\text { Companies } \\
\text { (within the } \\
\text { sample of } \\
4029 \\
\text { companies) }\end{array}$ & MSFI \\
\hline $\begin{array}{l}\text { RISK } \\
\text { MANAGMENT }\end{array}$ & YES & YES & YES & YES & YES & YES & YES \\
\hline $\begin{array}{l}\text { Participant in } \\
\text { process of risk } \\
\text { management }\end{array}$ & $\begin{array}{l}\text { BoD,MoD, } \\
\text { ALCO,CC } \\
\text { risk function } \\
\text { units }\end{array}$ & $\begin{array}{l}\text { Frame is } \\
\text { defined }\end{array}$ & & $\begin{array}{l}\text { Participants } \\
\text { in risk } \\
\text { management } \\
\text { are defined: } \\
\text { risk } \\
\text { management } \\
\text { system; } \\
\text { system of } \\
\text { internal } \\
\text { control, } \\
\text { internal } \\
\text { audit, } \\
\text { Actuary }\end{array}$ & $\begin{array}{l}\text { The } \\
\text { company } \\
\text { itself or CFO } \\
\text { (Chef } \\
\text { Financial } \\
\text { Officer) }\end{array}$ & Society & \\
\hline Type of risk & $\begin{array}{l}\text { All types are } \\
\text { shown, } \\
\text { capital } \\
\text { requirements } \\
\text { are shown } \\
\text { for } 3 \text { basic } \\
\text { only }\end{array}$ & $\begin{array}{l}11 \text { types of } \\
\text { risk } \\
\text { according to } \\
\text { the Law of } \\
\text { Banks }\end{array}$ & $\begin{array}{l}\text { Reporting } 2 \\
\text { types of risks } \\
\text { (insurance } \\
\text { and } \\
\text { financial) }\end{array}$ & $\begin{array}{l}8 \text { types of } \\
\text { risk } \\
\text { according to } \\
\text { the Law of } \\
\text { insurance }\end{array}$ & $\begin{array}{l}\text { Reporting (3) } \\
\text { Credit, } \\
\text { liquidity and } \\
\text { market risks }\end{array}$ & $\begin{array}{l}\text { Reporting (3) } \\
\text { credit, } \\
\text { liquidity and } \\
\text { market risks }\end{array}$ & $\begin{array}{l}\text { Defined } \\
3 \text { basic }\end{array}$ \\
\hline $\begin{array}{l}\text { Type of } \\
\text { reporting }\end{array}$ & $\begin{array}{l}\text { Financial } \\
\text { reports, } \\
\text { Annual } \\
\text { audited } \\
\text { reports, } \\
\text { Reports in } \\
\text { accordance } \\
\text { with Pillar } 3 \\
\text { of Basel II }\end{array}$ & $\begin{array}{l}\text { Quarterly } \\
\text { Reporting of } \\
3 \text { basic risk } \\
\text { types } \\
\text { according to } \\
\text { Pillar } 1 \text { of } \\
\text { the Basel II } \\
\text { on the } \\
\text { sector level }\end{array}$ & $\begin{array}{l}4 \\
\text { companies, } \\
\text { submitting } \\
\text { annual } \\
\text { reports and } \\
\text { reporting risk } \\
\text { management }\end{array}$ & $\begin{array}{l}\text { Quarterly } \\
\text { Reports of } \\
\text { basic } \\
\text { quantitative } \\
\text { requirements } \\
\text { within the } \\
\text { sector. No } \\
\text { reports } \\
\text { devoted to } \\
\text { the risk } \\
\text { management }\end{array}$ & $\begin{array}{l}\text { Financial } \\
\text { reports }\end{array}$ & $\begin{array}{l}\text { Financial } \\
\text { reports }\end{array}$ & $\begin{array}{l}\text { Reporting } \\
\text { (3) credit, } \\
\text { liquidity } \\
\text { and } \\
\text { market } \\
\text { risk }\end{array}$ \\
\hline Comments & $\begin{array}{l}\text { The banks } \\
\text { use } \\
\text { regulatory } \\
\text { framework } \\
\text { opportunity } \\
\text { to create } \\
\text { management } \\
\text { of risk based } \\
\text { on their risk } \\
\text { profiles. } \\
\text { Minimum of } \\
\text { requirements } \\
\text { have been } \\
\text { implemented } \\
\text { in all cases, } \\
\text { but } \\
\text { maximum } \\
\text { depends on } \\
\text { expertise of } \\
\text { professionals } \\
\text { and aim of } \\
\text { the capital } \\
\text { owner }\end{array}$ & $\begin{array}{l}\text { Credit, } \\
\text { market and } \\
\text { transactional } \\
\text { risk (3); } \\
\text { indirect and } \\
\text { direct } \\
\text { control }\end{array}$ & $\begin{array}{l}\text { Based on } \\
\text { available } \\
\text { data it might } \\
\text { be } \\
\text { concluded } \\
\text { that } \\
\text { insurance } \\
\text { sector is } \\
\text { lagging } \\
\text { behind } \\
\text { banking } \\
\text { industry. }\end{array}$ & $\begin{array}{l}\text { NBS web } \\
\text { site contains } \\
\text { financial } \\
\text { reports and } \\
\text { auditor's } \\
\text { opinion for } \\
\text { all } \\
\text { companies; } \\
\text { indirect and } \\
\text { direct } \\
\text { control. }\end{array}$ & $\begin{array}{l}\text { Based on } \\
\text { available } \\
\text { data it might } \\
\text { be } \\
\text { concluded } \\
\text { that the real } \\
\text { sector in } \\
\text { terms of risk } \\
\text { management } \\
\text { is far from } \\
\text { banking } \\
\text { industry } \\
\text { within this } \\
\text { field. }\end{array}$ & $\begin{array}{l}\text { Based on } \\
\text { available } \\
\text { data it might } \\
\text { be } \\
\text { concluded } \\
\text { that the real } \\
\text { sector in } \\
\text { terms of risk } \\
\text { management } \\
\text { is far from } \\
\text { banking } \\
\text { industry } \\
\text { within this } \\
\text { field. }\end{array}$ & \\
\hline
\end{tabular}

Source: The authors created a table on the basis of the available legislation, and information available on the websites of the analyzed sample of companies as well as the site of the APR for large and medium-size companies which are subject of analyses 
The common features of all reports are as follows:

(1) All 28 banks have following organizational structure of the risk management: the board of directors, the executive committee, the credit committee, the Committee for Asset and Liability Committee (ALCO) and function (department, service or department) to manage risk. Other participants depend on the type of the joint-stock company in question, such as the ownership structure and the basic activities that the bank is dealing with. In doing so, the two banks, especially in the risk management process, emphasize the CRO function. Furthermore, 27 banks provide information on the site about the function of risk management, out of which 25 have the appropriate sector or service (of which 3 banks have more sectors for risk management, namely, from 2 to 5 ).

2) The risks that are subject of special management are: credit, market, operational and liquidity risks. All the other mentioned (up to 17) are subject of assessment, control and monitoring, with a particular focus on capital requirements for credit, market and operational risks.

It can be concluded that the banks use the possibility of a regulatory framework to create risk management according to their risk profile. In doing so, they have always complied with the legal minimum, while the maximum depends on the expertise of individuals and the owners of capital, i.e., the banking group within which they operate. We emphasize that only five banks present an extremely high-quality risk management information in their release of data and information for Basel 2 Pillar 3 (on semi-annual and on annual bases).

The risk management process is significantly less developed within the insurance sector. The legislator prescribes the method of management in the insurance company (especially emphasized on the NBS site is the president of insurance and actuary, that pay special attention to risk management through capital requirement and measures to solvency insurance.

However, academic theories and teaching on the risk management process often fail to pay due attention to risk management in the insurance sector; they rather focus on quantitative indicators, based on previous experiences of monitoring (such as: solvency margin, guarantee reserves, asset quality, technically result), which is also stated in the report of the NBS as an improvement in corporate governance, the establishment of adequate systems of internal control and mapping of risk management procedures. Accordingly, the NBS web site has brought balance sheets and income statements (excel table) for all insurance companies and the auditor's opinion ( 2 sides), but only in case of 4 insurance companies and reinsurance companies the financial and annual reports can be found. According to them, the four companies are reporting on insurance risk and financial risk.

Referring to commercial companies,

1) Out of 7 listed companies, annual reports can be found on the websites of 4 companies, with information about the 3 main risks (credit, market and liquidity). Also, within the 4 reports it is stated that the company takes into account the risks, however, it is not defined which organizational bodies are responsible for dealing with them. Regarding the management of the funds, success is seen through the Report on cash flow management, and in particular showing liquidity risk management.

2) The APR site has published annual reports for 4022 large and medium-size unlisted companies in the real sector (which is a representative sample for making conclusions ). These reports contain information on 3 basic risks of business (i.e., credit, liquidity and market risk). In all of the reports it is stressed that the company takes care of risk of business without any referrence to the managment function in charge of it.

Unfortunately, the amount of information on risk management and resources present in the case of companies in the real sector is reduced to the legal minimum.

Finally, it can be concluded that the hypothesis is proven, which confirms that an institutionalized approach to risk management encourage the businesses to establish the risk management function (in case of banks and insurance companies). Further, it implies the development of a tool for liquidity management in companies (the case of banks and insurance companies). 
The global financial crisis has in many ways changed the company's everyday business perfomances. In order to survive, the company has to be confronted with various challenges. The main problem has been to record all risks to which the company is exposed. This has led to various changes within the company from the establishment of specific risk policies to the establishment of a system for risk assessment and special bodies dealing with risk management.

Within the paper it has been shown that an institutionalized approach to risk management encourages the companies to a establish risk management function (the case of banks and insurance companies). Further, it implies the development of a tool for liquidity management in companies (the case of banks and insurance companies). The conducted research indicated that the banking sector mostly made progress within risk management and cash management. The insurance sector is significantly lagging behind regarding these functions in comparison with the banking sector, while the real sector is considerably behind regarding the process of risk management and cash management. The companies in Serbia who recognized the importance of both management functions have engaged experts from the banking sector (risk sector, funds management sector, to work with legal entities) in order to become more successful in introducing both management functions (e.g., Atlatnik group, Victoria Group, Telenor, VIP, etc./ICAP, 2013).

Unfortunately, the research conducted in the period from 2012 to 2015 , pointed out that the functioning of the department for risk management functions properly only when it is imposed as an obligation by the regulatory body and when there are clearly defined public bodies which monitor the implementation of risk management at the level of a particular sector.

It can be concluded that further training is necessary of both the personnel and the regulator; the companies should develop better risk management within the context of overall corporate management businesses. The allocation of significant resources is necessary for IT support, and the effort as well provided by the companies for successful risk management implementation.

\section{LITERATURE:}

[1] Allen \& Overy (2012): Corporate Governance Comparative Study, http://www.corporategovernancecommittee.be

[2] Barjaktarović, L. (2015) Upravljanje rizikom, Univerzitet Singidunum, Beograd

[3] Barjaktarović, L., Vićentijević, K., Vjetrov, A. (2014) Risk analysis: Henkel Case, The Book of Proceedings FINIZ 2014, Belgrade, p. 13-15

[4] Barjaktarovic, L., Jecmanica, D. (2011), Osvrt na implementaciju standarda Bazela II u poslovanje bankarskog sektora Srbije, Menadzment 59, str. 71-77

[5] Beasey M.S., Clune R.\&Heranson D.R.(2005) "Enterprise Risk Management: An Empirical Analysis of Factors Associated with the Extent of Implementation"The Journal of Accounting and Public Policy , 2005, Vol. 24, 521-531

[6] Beasley, M.,Pagach, D., Warr,R. (2008), Information convezed in hiring announcments of senior executives oversiing enterprise-wide risk management processes, Journal of Accounting, Auditing and Finance pp.23:311-332

[7] Baxter, R., Bedard, J., Hoitash, R., Yezgel, A. (2013) Enterprise Risk management Program Quality: Determinants, Value Relevance and the Financial Crisis, Contemporary Accoutning Research, Vol. 30 No.4, pp.1264-1295

[8] Beogradska berza (2015) Podaci iz trgovanja / Dnevni podaci (available on site: http://www.belex.rs/trgovanje/dnevni_podaci, date of access 01/09/2016)

[9] Caruntu G.A i Romanescu M.L.(2008) :" Treasury cash ows in the enterprise“,University of Constantin Brancusi Targu Jiu, Romania Online at http://mpra.ub.uni-muenchen.de/11238/ MPRA Paper No. 11238

[10] COSO (2004) Enterprise Risk Mnagement - Integraed Framework (available on site: www.coso.org/documents/COSO_ERM_ExecutiveSummery.pdf)

[11] Directive 2006/43/EC of the European parliament and of the Council, consolidated text (2014), http://eur-lex.europa.eu/legal-content datum pristupa 14.01.16.

[12] Đjorđević, M., Krstić, J. (2012) Interna kontrola i upravljanje rizikom preduzeca od tradicionalnog do revidiranog COSO modela. Ekonomske teme, 20122 pp. 151-166 
[13] ICAP (2013) "How do CFOs enforce a culture of Credit prudence without constraining the sales potential of their companies", 3rd Credit Risk Management Conference, Belgrade, hotel Metropol [http://www.icap.rs/Default.aspx?id=9215\&nt=18\&lang=2, date of access 01/09/2016]

[14] Lajili K. (2009): Corporate Risk Disclosure and Corporate Governance,Journal of Risk and Financial Management 2(2009) 94-117

[15] Mayers S (1984): The Capital Structure Puzzle, National Bureau of Economic Research, Cambridge, USA http://www.nber.org/papers/w1393.pdf

[16] Medjunarodna finansijska korporacija /IFC/ (2011) Korporativno upravljanje - Prirucnik, Beograd

[17] Međunarodni računovodstveni standardi (IAS), www.mfin.gov.rs/pages/article.php?id=10262(posebno vazan za istrazivanje MSFI 7)

[18] Narodna banka Srbije: http://www.nbs.rs/internet/cirilica/50/index.html, datum pristupa 09.01.2016.)

[19] McKinsey reaserch: Improving board governance: McKinsey Global Survey results (2013),http://www.mckinsey.com/insights/strategy , uvid 14.01.16

[20] Nikolić J Mr, Erić J. Mr (2011): Uloga i vrste upravnih odbora u korporativnom upravljanju, Managment br.60

[21] NYSE: Corporate Governance Guide,2014, Wight pages Itd, London UK ,ISBN: 978- 0-9565842-6-7 https://www.nyse.com/

[22] Odluka o objavljivanju informacija i podataka banke (2015) Sl.glasik Republike Srbije, br.4/2015

[23] Odluka o sistemu upravljanja u drustvima za osiguranje i reosiguranje (2015) SI.glasnik Republike Srbije br. 51/2015

[24] OECD (2014), Risk Management and Corporate Governance, Corporate Governance, OECD Publishing.http://dx.doi.org/10.1787/9789264208636-en

[25] Site of Basel Commitee, http: www.bis.org http://www.bis.org/bcbs/publications.htm (date of accessw 01/09/2016)

[26] Site of Commitee of European Insurance and Occupational Pensions Supervision, https://eiopa.europa.eu/regulation-supervision (date of access 01/09/2016)

[27] Site of APR www.apr.gov.rs

Receieved:February 2016. Accepted: May 2016.

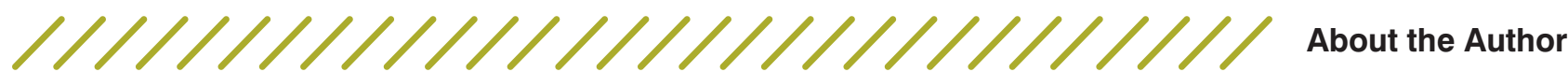

\section{Zlatija Jelenković \\ Raiffeisen bank a.d. Beograd zlatija.jelenkovic@raiffesenbank.rs}

Zlatija Jelenković has a Master degree in Economic Sciences in the sector of macroeconomics, acquired at the Faculty of Economics University of Belgrade. She has pursued a banking career since 1988 until the present moment, starting from Jugobanka osnovna banka Beograd to Raiffeisen banka a.d. Beograd, on various managerial positions. She is the author of several articles published in Serbia and abroad in scientific and professional journals (for example, Factor scan, Bankarstvo,etc.).

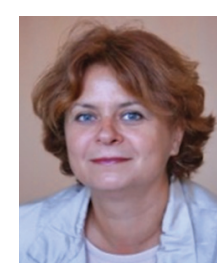

\section{Lidija Barjaktarović University Singidunum, Beograd}

Lidija Barjaktarović has a PhD in Economic Sciences in the sectors of banking and finance. Since 2008 she teaches the courses in Banking, Risk Management and Corporate Finances at the Singidunum University in Belgrade. She has been Head of Master study programmes: Business Economics and Public Sector Management at the Singidunum University. She pursued a banking career in the period from 1998 to 2008. She started in Jugobanka A.D. Belgrade, after which she moved to Societe General Yugoslav Bank a.d. Belgrade, and then to Raiffeisen Bank a.d. Belgrade, to be promoted to the Head of the Regional Branch of Central Serbia. In 2005 she moved to

Erste Bank a.d. Novi Sad to become the Director of Corporate Division. At the end of 2007 Erste Group appointed her a member of the Corporate Board and Corporate Working Group on the level of the Erste Holding Vienna. 